\title{
Assessment of Degradations/Defects and Maintenance of Administrative Primary and Secondary School Buildings of the City of Bafoussam, Cameroon
}

\author{
David Vom Tahi Onana \\ Department of Civil Engineering, Advanced Technical Teachers Training College, University of Douala, PO \\ BOX 1872, Douala, Cameroon \\ Blaise Ngwem Bayiha* \\ Department of Civil Engineering, Advanced Technical Teachers Training College, University of Douala, PO \\ BOX 1872, Douala, Cameroon \\ *Corresponding author email: ngwembayiha@yahoo.fr \\ Didier Fokwa \\ Department of Civil Engineering, Advanced Technical Teachers Training College, University of Douala, PO \\ BOX 1872, Douala, Cameroon \\ Robert Nzengwa \\ Faculty of Industry Engineering, University of Douala, PO BOX 2701, Douala, Cameroon
}

\begin{abstract}
This paper reports the findings of a survey on assessment of degradations/defects and maintenance of administrative primary and secondary school buildings of the city of Bafoussam, Cameroon. Data were collected with the use of structured questionnaires as shown in appendix II administered on various managers of public primary and secondary schools in the three districts of Bafoussam namely, Bafoussam I, Bafoussam II and Bafoussam III. Data were analysed with basic descriptive tools such as percentage. The results showed that the primary schools buildings in the city of Bafoussam are more degraded than those of secondary schools as an example $98 \%$ of primary school buildings in the city of Bafoussam show an aging of the paint on the walls, i.e. 127 buildings, while those of secondary school buildings show $86 \%$ i.e. 157 buildings. $85 \%$ of primary school buildings in the city of Bafoussam have a ceiling in poor condition i.e. 111 buildings, while those of secondary schools buildings have $76 \%$ i.e. 132 buildings. The secondary school buildings in the city of Bafoussam have undergone more maintenance works than those of primary schools.
\end{abstract}

Keywords: Degradations/defects, Maintenance, Primary school buildings, Secondary school buildings, Bafoussam

DOI: $10.7176 / \mathrm{CER} / 12-6-03$

Publication date:June $30^{\text {th }} 2020$

\section{Introduction}

Since ancient times, housing has always been at the center of human concerns. Administrative buildings represent an important part of the heritage of a state, they are the workplace of its personnel performing administrative tasks. School buildings are the most numerous in this category. A building in good condition provides a framework for excellence in transmission of knowledge to learners and a conducive and safe environment for proper service delivery for supervisory staff on the other hand. Well planned maintenance will first protect long-term assets whilst save revenue because the costs of emergency repair of a failure exceed those of well planned maintenance. In the cases of our school buildings in particular those of the city of Bafoussam suffer from a real maintenance problem. This is how we can observe facades covered with mold, cracked walls, torn sheets, poor condition of the coating on the walls, poor condition of the paint, cracking with peeling of the concrete on the elements of structures such as columns, beams, slabs etc. poor condition of the foundation and erosion, defective ceiling, etc. it undoubtedly and indisputably turns out that without maintenance their operation would be ineffective and the rapid and early deterioration would cause serious hazard and discomfort which could lead to the collapse of the various structural elements or even to the total collapse of the building. According to Perret (1999), building maintenance work requires skills in the use of technical equipment and adequate maintenance make buildings last longer (Olubi and Adewolu, 2018).

Buildings are structures constructed to serve as shelter for man, his properties and activities ((Bikoko et al. 2019; Tchamba \& Bikoko, 2016; Tahi Onana et al., 2020; Amadi et al. 2012; Ayuba et al. 2012; Oseghale et al. 2015; Tauheed, 2007). They are expected to be properly designed, planned, constructed, managed and maintained to offer desired satisfaction to the occupant (Tahi Onana et al., 2020 ; Olubi and Adewolu, 2018 ; Babalola, 2015). 
Some studies have been conducted around the world on maintenance of school buildings as example, Tayeh et al. (2016) studied the effects of faulty design phase on school buildings maintenance in Gaza Strip. They reported that the important factors that leading to defects in the design stage were: lack of workshops to discuss construction problems between project parts, inadequate QA/QC programs during design stage, lack of auditing and archiving of approved as-built drawing documents electronically. In a study on maintenance of government buildings in Ghana, Twumasi-Ampofo et al. (2017) stated that absence of planned maintenance policy and improper maintenance, pressure on facilities vis-à-vis age of the buildings cause elements of building such as doors, windows, ceilings, cables etc. in deplorable state. Tayeh et al. (2017) studied the effects of construction phase errors on school buildings maintenance in Gaza Strip. The authors recommended that a strict quality assurance and quality control $(\mathrm{QA} / \mathrm{QC})$ program should be implemented by the parties to construction to insure that project execution complies with the latest economical and practical specifications. Wuni et al. (2018) reported that the empirical causes of poor facility management were: lack of professional managers, attitude of deferred maintenance, budgetary limit on maintenance expenditure, sidelined in the financial planning and capital budgeting of institutions, amongst others. Eghan (2014) developed a framework for maintenance management for senior high schools in Ghana.

So far, no information or data is available from this study area on assessment of degradations/defects and maintenance of administrative primary and secondary school buildings.

This paper was aimed at assessing the degradations/defects and maintenance of administrative primary and secondary school buildings of the city of Bafoussam, Cameroon.

\section{Description of the study area}

\subsection{Relief and soil}

The city of Bafoussam is built in the lower hills of Banengo and Baleng, which are covered with savannah vegetation, the city is located at $1450 \mathrm{~m}$ above sea level and is built in steps on the perimeters of the Tamdja (1st floor) districts, commercial centre Djemoun (2nd floor), Djeleng (3rd floor), lower the corners called rural municipalities and Tougan on the 4th floor.

\subsection{Hydrology}

The city of Bafoussam is not very rich in hydraulic resources; the main river is the Mifi which runs along the city in the southern part, accompanied by other small streams including the Megang, Nlom and Vava. as an attraction, the fall of Metche and Lake Baleng.

Other informations on the city of Bafoussam such as the population and density, temperature, precipitation etc... can be found in Tahi Onana et al. (2020).

The map showing the three districts of Bafoussam, namely Bafoussam I, Bafoussam II and Bafoussam III can be seen in Figure 1.

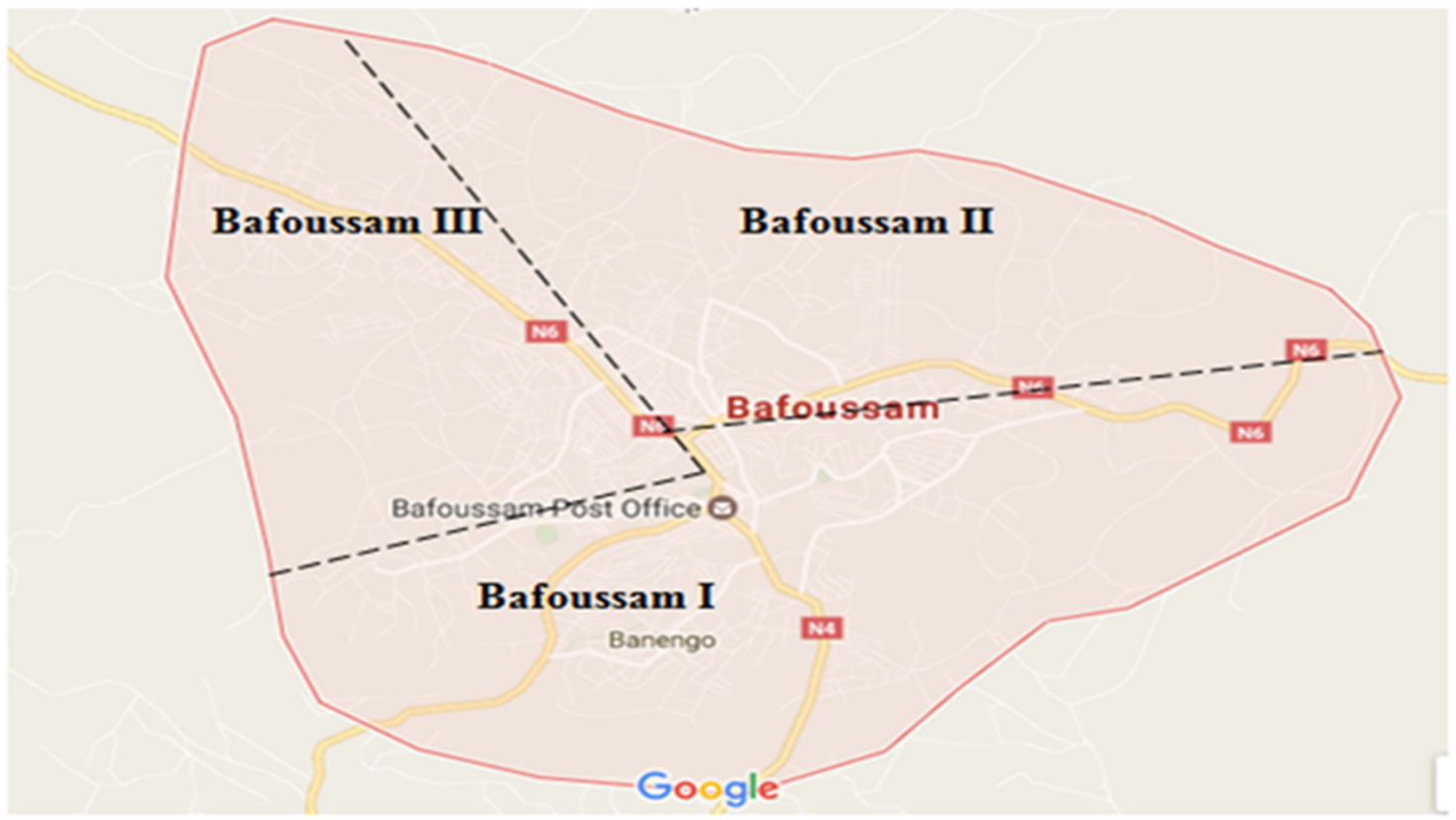

Figure 2 : Carte de la ville de Bufoussum (Source : Wikipédia)

Figure 1. Map of the city of Bafoussam (Tahi Onana et al., 2020) 


\section{Research methodology}

This work consisted in making an inventory of the administrative school buildings of the city of Bafoussam, in identifying and quantifying all the degradations or defects present in each building, and in all the buildings, to bring out the problems related to their operation or their physical aspect and to assess the maintenance work undertaken on these buildings. To achieve this goal, the diagnostic aid sheets informing us of the faults or damage encountered in all of the buildings have been designed. These files allowed us to identify and examine by summary and detailed visual inspections of all the buildings by public school establishment then to examine the potential defects or degradations encountered on these buildings, we also took photos of the main degradations. The calculations are represented in the tables respectively covering the buildings of the primary and secondary schools and the total, the figures and the histograms are also plotted. This work was carried out during the period of MarchApril 2017.The data collected were analyzed using descriptive and analytical statistics.

\subsection{Questionnaire design}

The survey sheets were administered to the various managers of the 46 public primary and secondary schools in the three districts of Bafoussam, namely Bafoussam I, Bafoussam II and Bafoussam III. The names of these schools, the total number of buildings contained in each establishment school, the number of classrooms and others, the number of offices and the number of toilets or latrine blocks of these schools are given in appendix I of this article. The survey sheets designed ask the following questions: How many buildings does the establishment have? How do the buildings look at first sight? Does the establishment have a daycare service? Does the establishment have a building maintenance service? Is there a preliminary assessment study of the repair work? Who takes care of cleaning your premises? What surfaces are cleaned regularly? How often is it cleaned? Is there a periodic monitoring method for the various buildings in your establishment? Is there a building maintenance frequency? Where does the funding for the maintenance of your buildings come from? The other questions are given on the survey sheet which can be found in Annex I of this article.

\section{Results analysis and discussion}

The results of the survey conducted reveal that the city of Bafoussam has nearly 46 schools spread across the city center and its outskirts, including 31 primary schools and 15 secondary schools, and have nearly 312 buildings housing students and staff in the establishment. These buildings include classrooms, buildings for offices, specialized rooms, buildings for latrines or toilets and buildings for school canteens. These buildings are on one level and level buildings.

$87 \%$ of these school buildings in the city of Bafoussam are more than 10 years old, i.e. 271 buildings, $50 \%$ are between 10 and 30 years old i.e. 156 buildings, $27 \%$ are between 30 and 50 years old i.e. 84 buildings and $10 \%$ an age between 50 and 100 years i.e. 31 buildings. The majority of primary school buildings are old.

Table 1 and Figure 2 show the state of wood joinery, metal joinery and glazing of public primary and secondary school building in the city of Bafoussam. We observe the very poor condition of the metal carpentry, which is linked to the lack of paint, aging, student stinginess and acts of vandalism. In addition, the wood joinery and the glazing show just a few dilapidations, even if the glazing is rare and sometimes nonexistent. $78 \%$ of the primary school buildings of the city of Bafoussam present a very bad state in metallic joinery i.e. 102 of buildings, while $65 \%$ of secondary school buildings are in poor condition with metallic carpentry i.e. 119 buildings. The school buildings of primary schools in the city of Bafoussam are more degraded than those of secondary schools in terms of carpentry (wood carpentry, metal carpentry and glazing).

The combined degradations or defects on the wood joinery, the metallic joinery and the glazing of the administrative primary and secondary school buildings of the city of Bafoussam are given in figure 3. Figure 4 illustrates the poor condition of the doors of some school buildings.

Table 1.Carpentry condition

\begin{tabular}{|c|c|c|c|c|c|c|}
\hline $\begin{array}{c}\text { Degradations/defects on } \\
\text { buildings }\end{array}$ & \multicolumn{2}{|c|}{ Primary schools } & \multicolumn{2}{c|}{ Secondary schools } & \multicolumn{2}{c|}{ Total } \\
\hline $\begin{array}{c}\text { Number of } \\
\text { buildings } / 130\end{array}$ & $\%$ & $\begin{array}{c}\text { Number of } \\
\text { buildings } / 182\end{array}$ & $\%$ & $\begin{array}{c}\text { Number of } \\
\text { buildings } / 312\end{array}$ & $\%$ \\
\hline $\begin{array}{c}\text { Poor condition of the } \\
\text { woodwork }\end{array}$ & 26 & 20 & 11 & 06 & 37 & 12 \\
\hline $\begin{array}{c}\text { Poor condition of metal } \\
\text { carpentry }\end{array}$ & 102 & 78 & 119 & 65 & 221 & 71 \\
\hline Poor state of the glazing & 06 & 02 & 04 & 02 & 10 & 03 \\
\hline
\end{tabular}




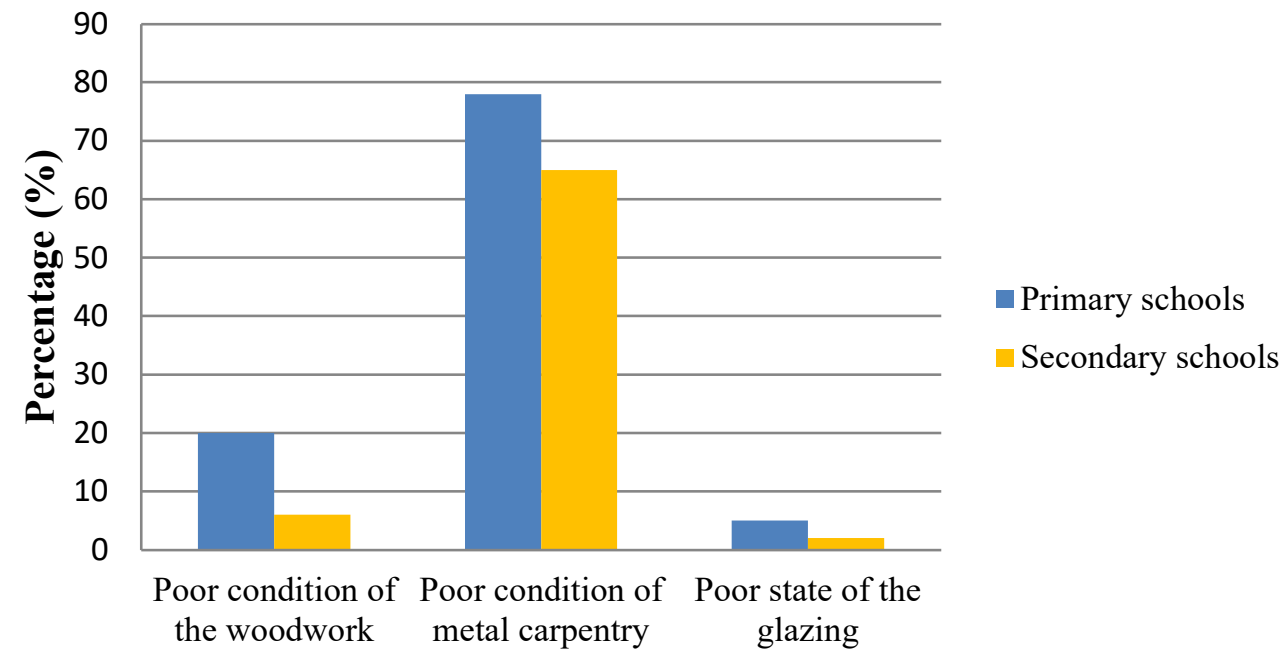

Figure 2.Histogram of the state of the carpentry of public primary and secondary school buildings in the city of Bafoussam

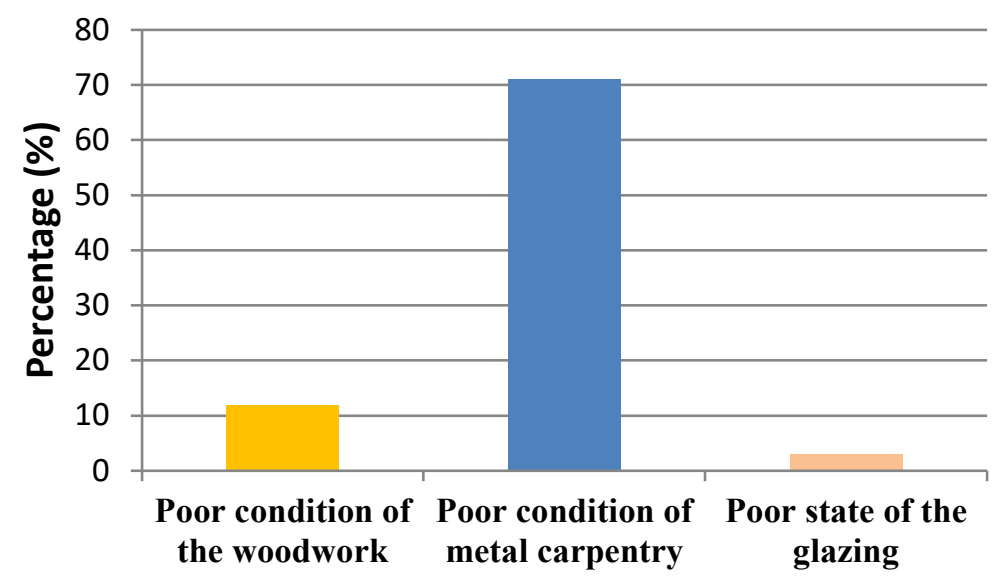

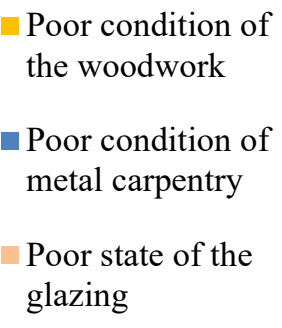

Poor condition of

Poor condition of

Poor state of the glazing

Figure 3.Global histogram of the state of the carpentry of public primary and secondary school buildings in the city of Bafoussam
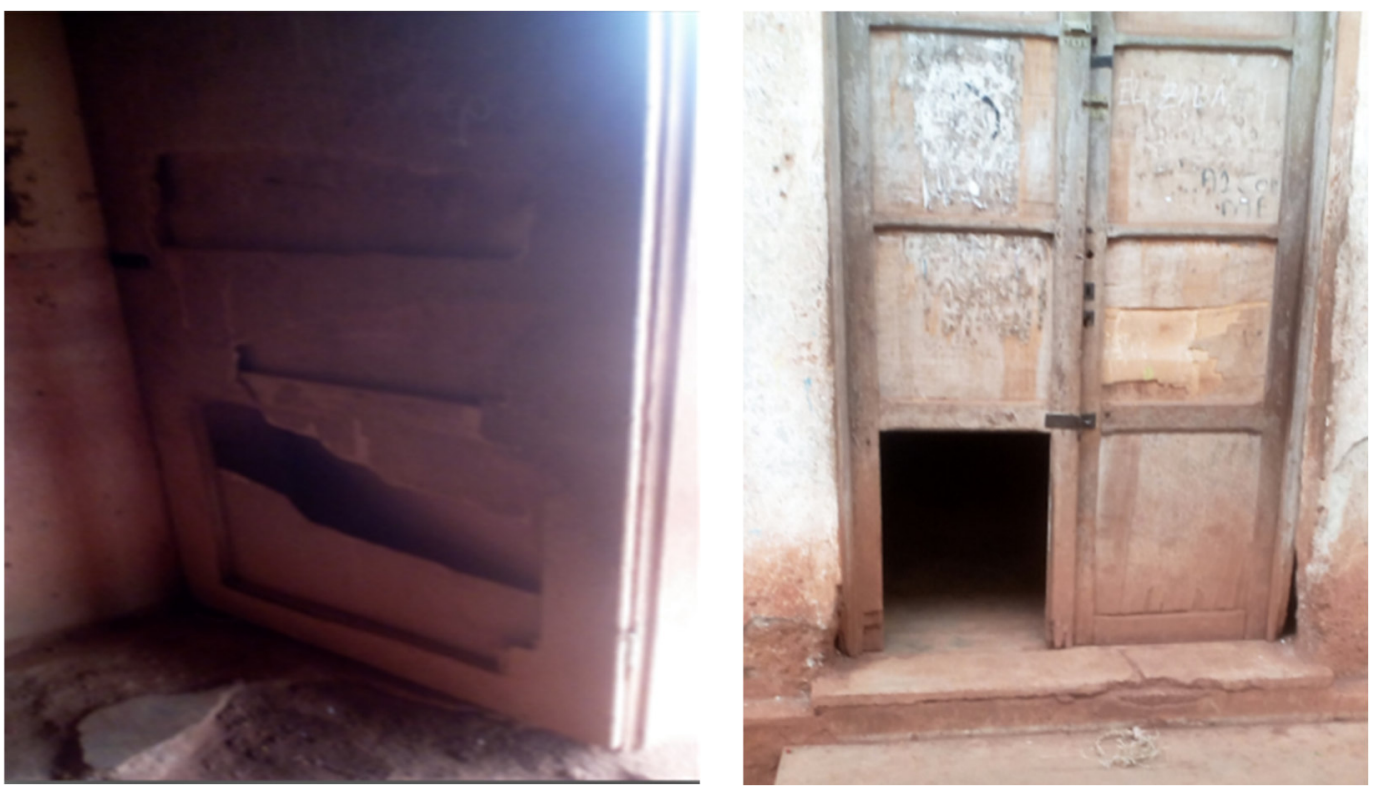

Figure 4. Poor condition of the doors of some school buildings 
Table 2.State of electricity and fire safety

\begin{tabular}{|c|c|c|c|c|c|c|}
\hline Degradations/defects on buildings & \multicolumn{2}{|c|}{ Primary schools } & \multicolumn{2}{|c|}{ Secondary schools } & \multicolumn{2}{c|}{ Total } \\
\hline & $\begin{array}{c}\text { Number of } \\
\text { buildings } / 130\end{array}$ & $\%$ & $\begin{array}{c}\text { Number of } \\
\text { buildings } / 182\end{array}$ & $\%$ & $\begin{array}{c}\text { Number of } \\
\text { buildings } / 312\end{array}$ & $\%$ \\
\hline Bulbs and sockets not working & 115 & 88 & 91 & 91 & 206 & 66 \\
\hline Faulty electrical installations & 59 & 45 & 38 & 38 & 97 & 31 \\
\hline Insufficient bulbs and sockets & 61 & 47 & 46 & 46 & 107 & 34 \\
\hline Absence of fire extinguishers & 124 & 95 & 168 & 92 & 292 & 94 \\
\hline
\end{tabular}

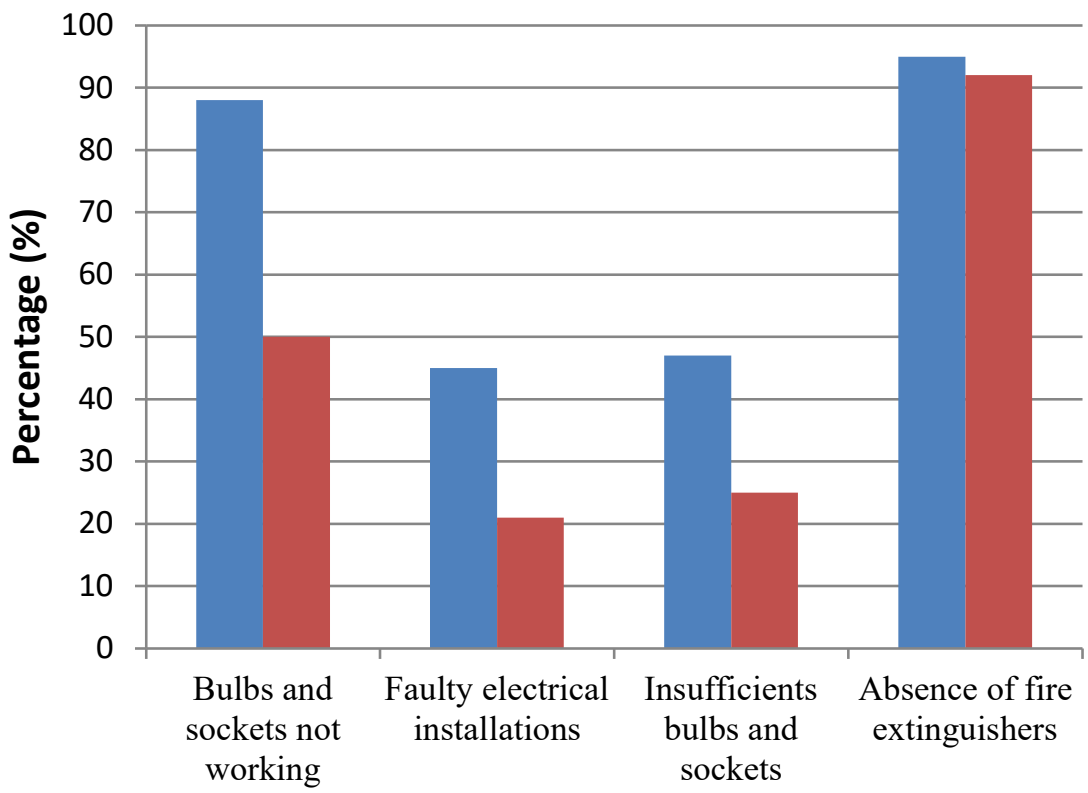

- Primary schools

- Secondary schools

Figure 5. Histogram of the state of electricity and fire safety of public primary and secondary school buildings in the city of Bafoussam

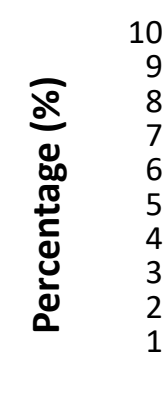

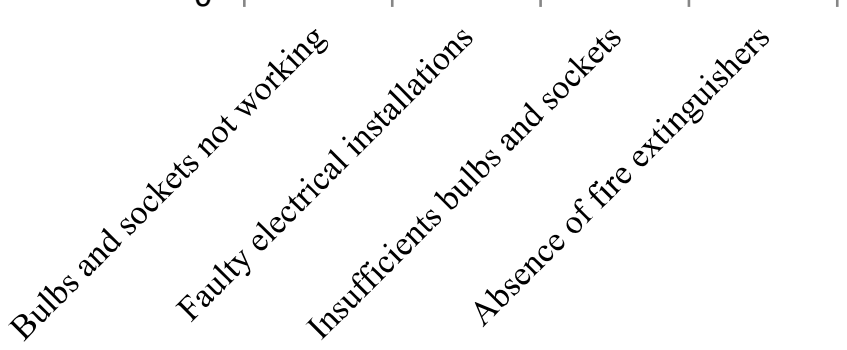

Bulbs and sockets not working

Faulty electrical installations

Insufficients bulbs and sockets

Absence of fire extinguishers

Figure 6.Global histogram of the state of electricity and fire safety of public primary and secondary school buildings in the city of Bafoussam

The state of the electricity and fire safety of school buildings in the city of Bafoussam are given in Table 2 and in Figure 5. Figure 6 reports the combined degradations or defects on electricity and fire safety of the administrative buildings of the primary and secondary schools in the city of Bafoussam. In general, the electricity and fire safety of school buildings in the city of Bafoussam are in an deplorable condition. We observe that certain school buildings have non-functional light bulbs and sockets while other school buildings do not even have light bulbs and sockets, jeopardizing the smooth running of school activities, particularly in the specialized classrooms 
(laboratories, multimedia rooms, workshops etc.). The often apparent and unprotected electrical installations jeopardize the safety of students and staff. We note the absence of fire extinguishers in the workshop rooms. The poor state of the electricity is due to the use of unskilled labor, the poor quality of the sockets, the poor quality of light bulbs and electrical equipment used and the students' bad behavior.

The school buildings of primary schools in the city of Bafoussam are more degraded in the field of electricity and fire safety than those of secondary schools.

Table 3.State of sanitation, plumbing and sanitary facilities

\begin{tabular}{|c|c|c|c|c|c|c|}
\hline \multirow{2}{*}{ Degradations/defects on buildings } & \multicolumn{2}{|c|}{ Primary schools } & \multicolumn{2}{|c|}{ Secondary schools } & \multicolumn{2}{c|}{ Total } \\
\cline { 2 - 7 } & $\mathrm{N} / 130$ & $\%$ & $\mathrm{~N} / 182$ & $\%$ & $\mathrm{~N} / 312$ & $\%$ \\
\hline Water drop nonexistent or in bad condition & 118 & 91 & 91 & 50 & 209 & 67 \\
\hline Toilet or latrine in poor condition & 23 & 62 & 14 & 58 & 37 & 61 \\
\hline Absence of channels or channels in poor condition & 125 & 96 & 113 & 62 & 172 & 55 \\
\hline
\end{tabular}

$\mathrm{N}=$ Number of buildings containing this defect

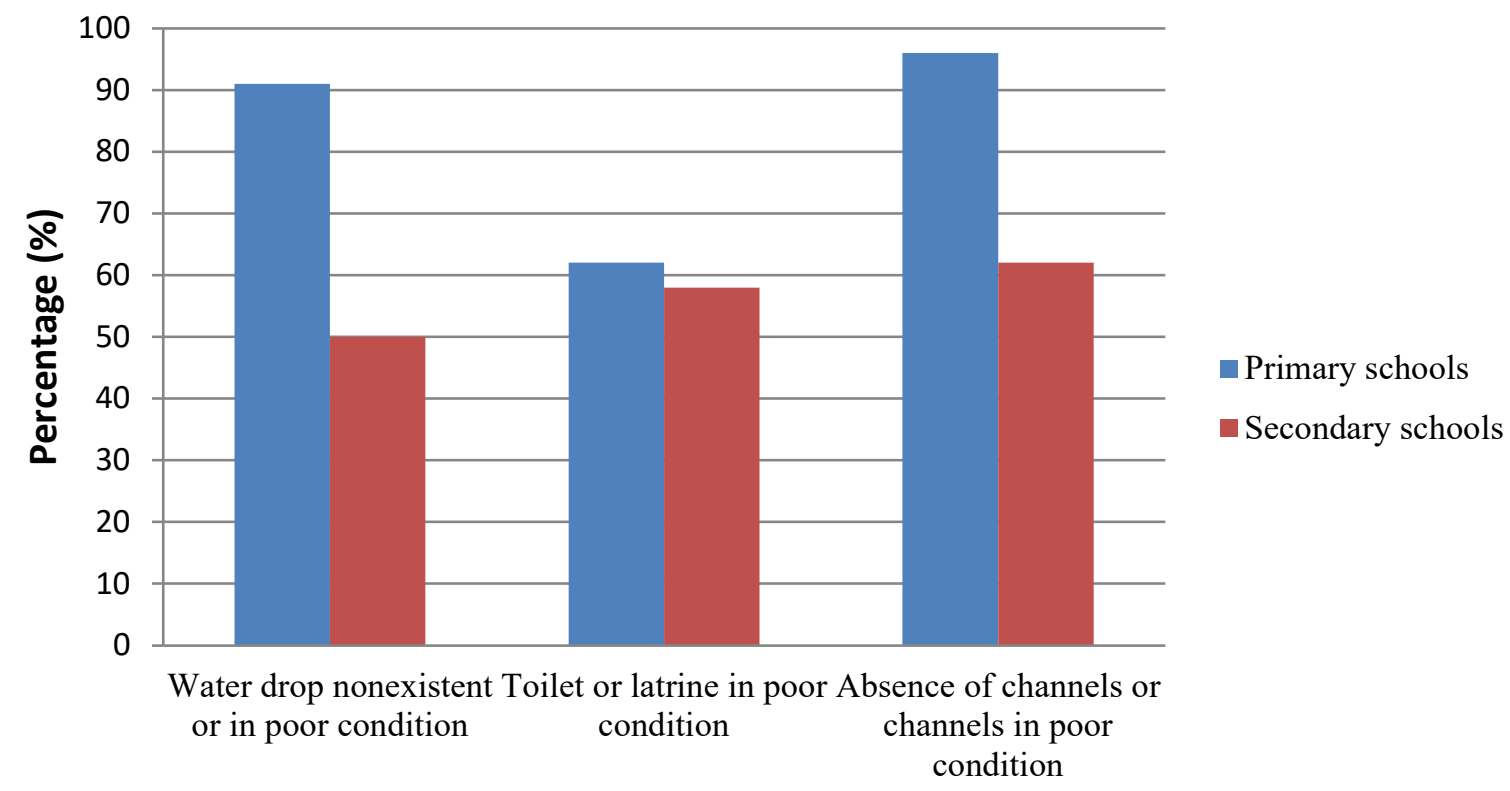

Figure 7. Histogram of the state of sanitation, plumbing and sanitary facilities of public primary and secondary school buildings in the city of Bafoussam

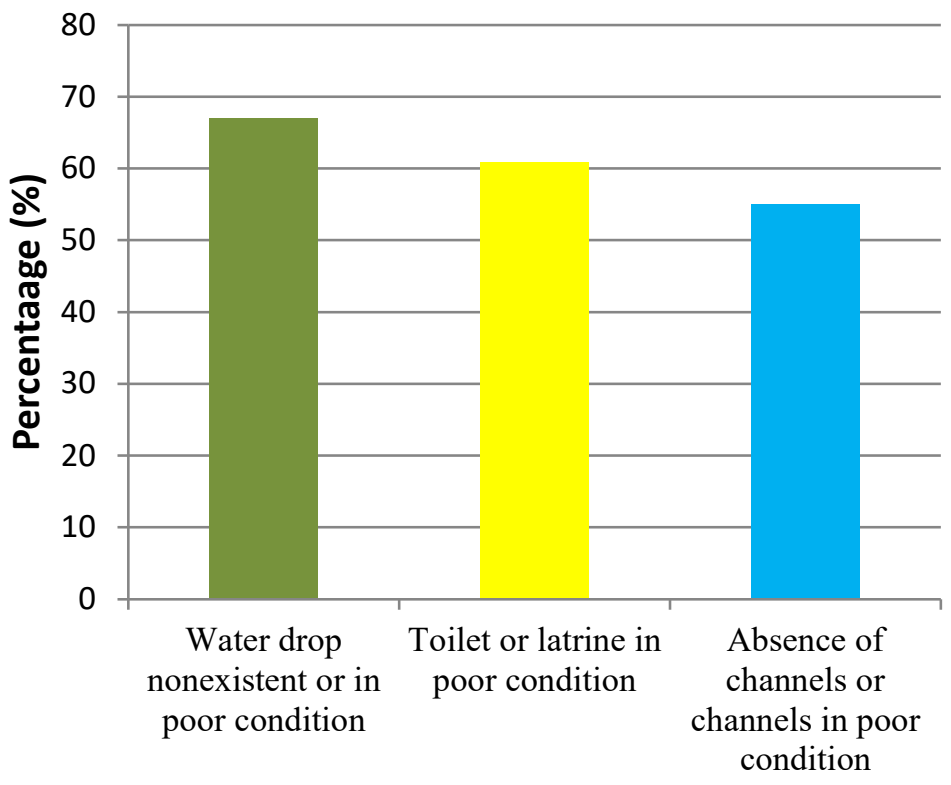

Water drop nonexistent or in poor condition

Toilet or latrine in poor condition

Absence of channels or channels in poor condition

Figure 8. Global histogram of the state of sanitation, plumbing and sanitary facilities of public primary and secondary school buildings in the city of Bafoussam 


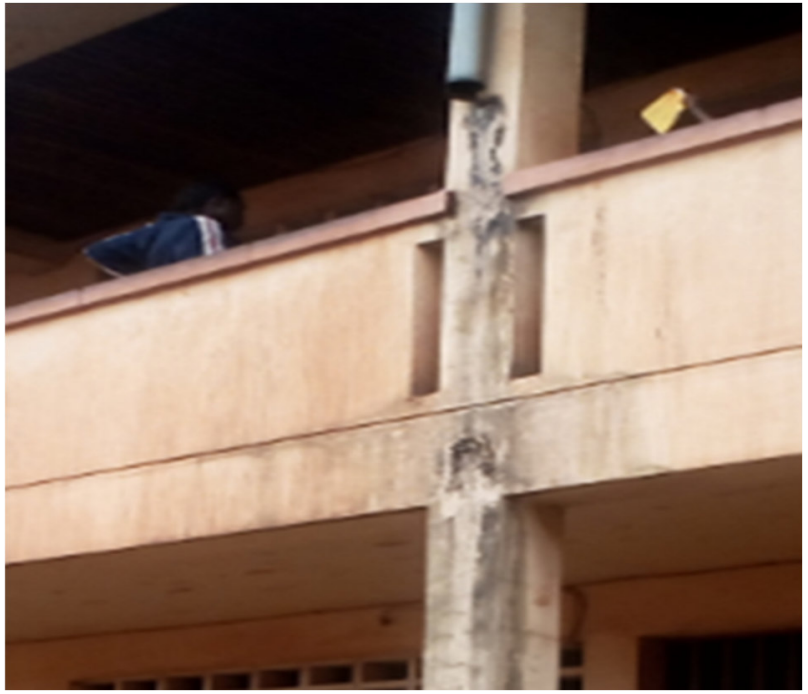

Figure 9. Defective water descent

Figure 7 and Table 3 report the state of sanitation, plumbing and sanitation facilities. The combined degradations or defects in the field of sanitation, plumbing and sanitary facilities of administrative buildings of primary and secondary schools in the city of Bafoussam are listed in Figure 8.

The state of sanitation is generally poor; the problem of non-functionality of the toilets is due to:

- A very aging water supply network

- Under sizing of the piping that does not take into account population growth

- Absence or low pressure of water

- Misuse of sanitation facilities by students and school staff

- The use of unskilled maintenance labor

The nonexistent or poor water downspouts (Figure 9) and the absence or poor condition of the channels (Figure 12) are respectively the cause of the deterioration of the paintwork of the building and the erosion which causes bare foundations and steps.

Table 4. State of the exterior fittings

\begin{tabular}{|c|c|c|c|c|c|c|}
\hline \multirow{2}{*}{$\begin{array}{c}\text { Degradations/defects on } \\
\text { buildings }\end{array}$} & \multicolumn{2}{|c|}{ Primary schools } & \multicolumn{2}{|c|}{ Secondary schools } & \multicolumn{2}{c|}{ Total } \\
\cline { 2 - 7 } & $\begin{array}{c}\text { Number of } \\
\text { buildings } / 130\end{array}$ & $\%$ & $\begin{array}{c}\text { Number of } \\
\text { buildings } / 182\end{array}$ & $\%$ & $\begin{array}{c}\text { Number of } \\
\text { buildings } / 312\end{array}$ & $\%$ \\
\hline $\begin{array}{c}\text { No paving or paving around } \\
\text { buildings }\end{array}$ & 98 & 75 & 74 & 41 & 172 & 55 \\
\hline Brush around buildings & 03 & 02 & 02 & 01 & 5 & 03 \\
\hline
\end{tabular}

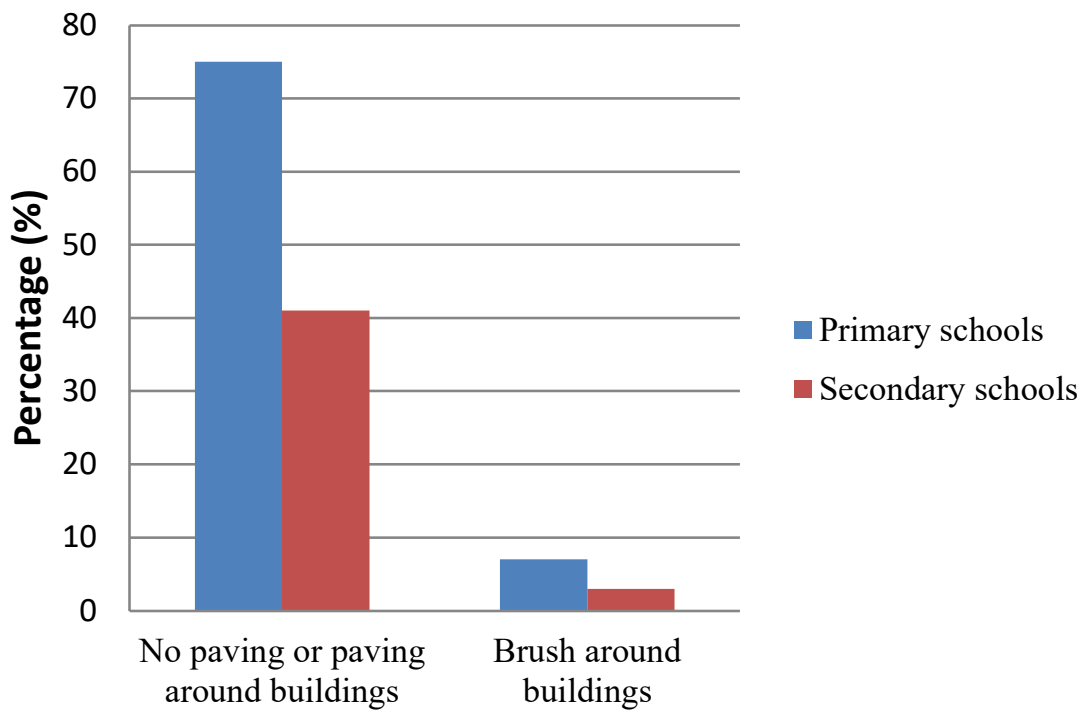

Figure 10. Histogram of the state of the exterior fittings of public primary and secondary school buildings in the city of Bafoussam 


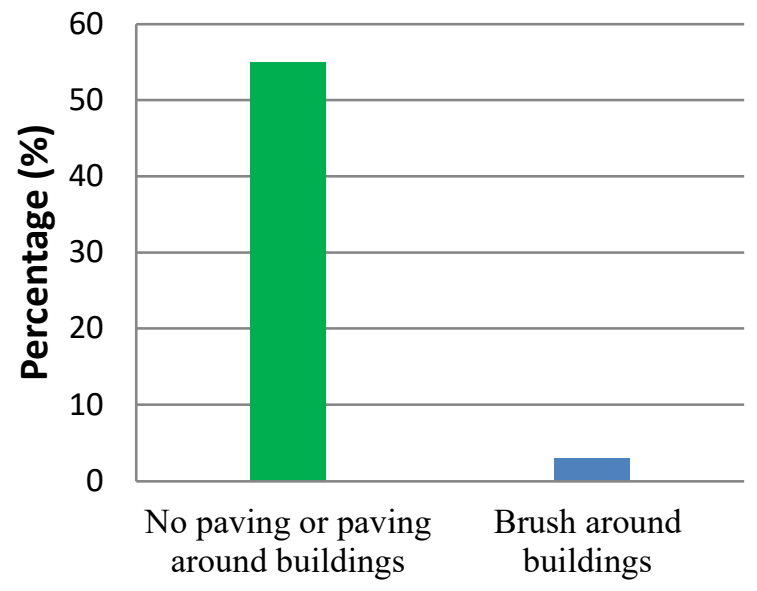

No paving or paving around buildings

- Brush around buildings

Figure 11. Global histogram of the state of the exterior fittings of public primary and secondary school buildings in the city of Bafoussam

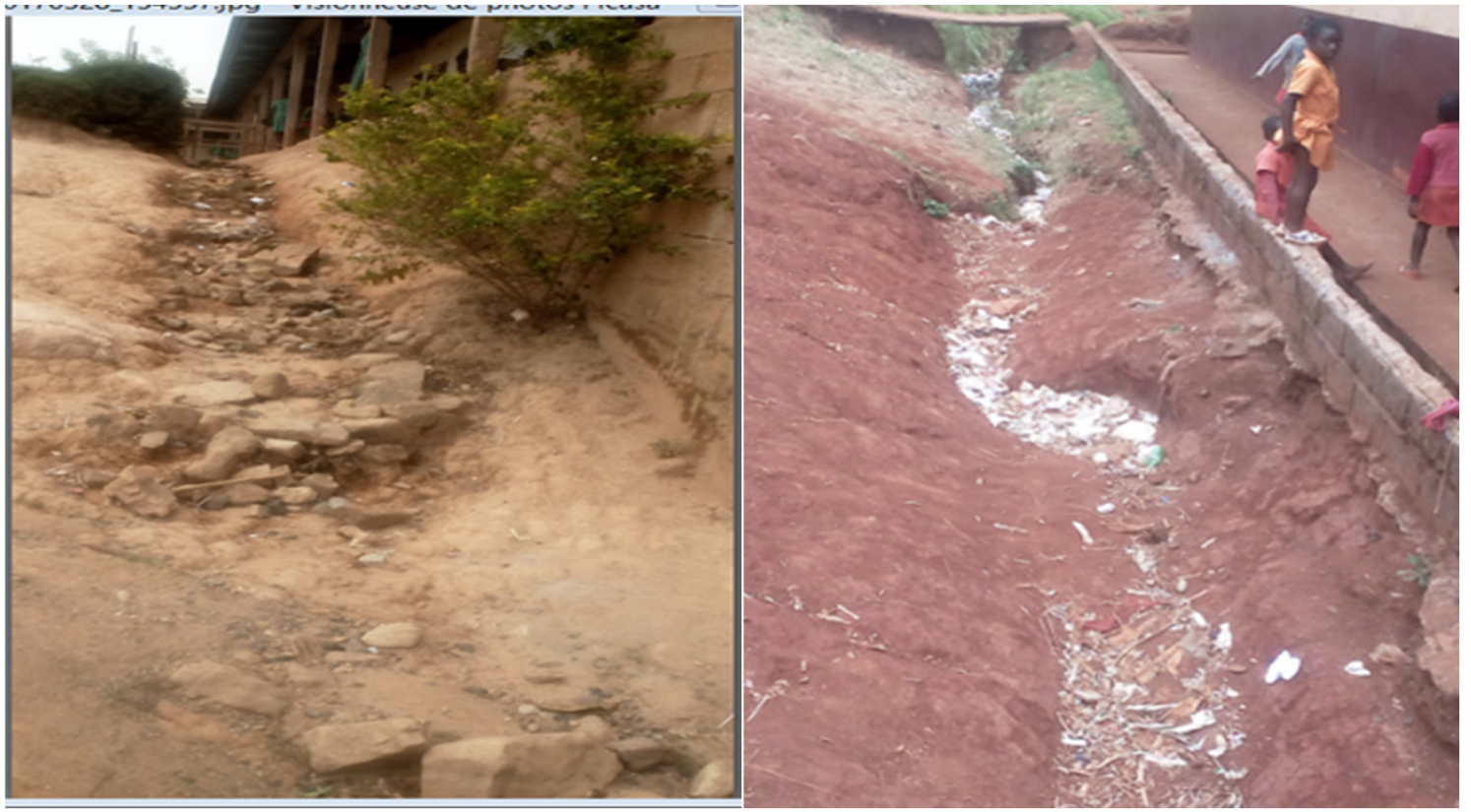

Figure 12.Absence or poor condition of the channels

Figure 10 and Table 4 show the external appearance of public school buildings for primary and secondary schools in the city of Bafoussam. Figure 11 shows the overall external state.

One of the positive points here is the effectiveness of the cleaning work around the buildings by the students during manual work sessions. This is what explains the absence of brush around school buildings. Furthermore, the absence of paving or paving around the buildings promotes erosion and this is what is causing the bare foundations (Figure 15) of the buildings without channels. The school buildings of primary schools in the city of Bafoussam are more degraded than those of secondary schools in external appearance. 
Table 5. Defects in General aspect

\begin{tabular}{|c|c|c|c|c|c|c|}
\hline \multirow{2}{*}{ Degradations/defects on buildings } & \multicolumn{2}{|c|}{ Primary schools } & \multicolumn{2}{|c|}{ Secondary schools } & \multicolumn{2}{|c|}{ Total } \\
\cline { 2 - 7 } & $\begin{array}{c}\text { Number of } \\
\text { buildings } / 130\end{array}$ & $\%$ & $\begin{array}{c}\text { Number of } \\
\text { buildings } / 182\end{array}$ & $\%$ & $\begin{array}{c}\text { Number of } \\
\text { buildings } / 312\end{array}$ & $\%$ \\
\hline Poor plaster condition & 21 & 16 & 16 & 9 & 37 & 12 \\
\hline Poor paint condition & 127 & 98 & 157 & 86 & 284 & 91 \\
\hline Floor covering in poor condition & 63 & 48 & 75 & 41 & 138 & 44 \\
\hline Humidity & 12 & 9 & 04 & 2 & 16 & 05 \\
\hline Crack with concrete peeling & 04 & 3 & 05 & 3 & 09 & 03 \\
\hline Poor foundation condition and Erosion & 67 & 52 & 68 & 37 & 135 & 43 \\
\hline Waterproofing and roof in poor \\
condition
\end{tabular}
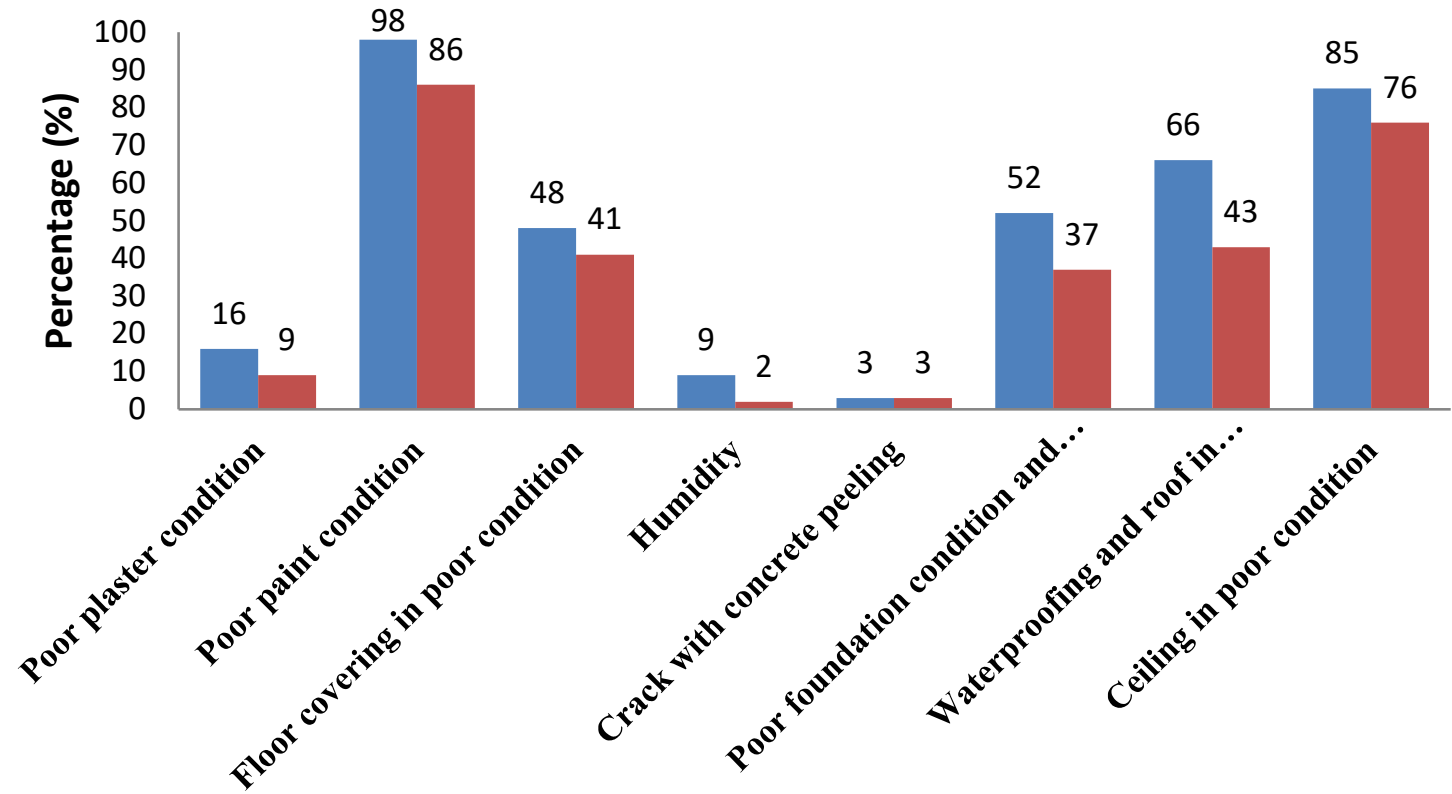

- Primary schools $\quad$ Secondary schools

Figure 13. Histogram of the general aspect of public primary and secondary school buildings in the city of Bafoussam 


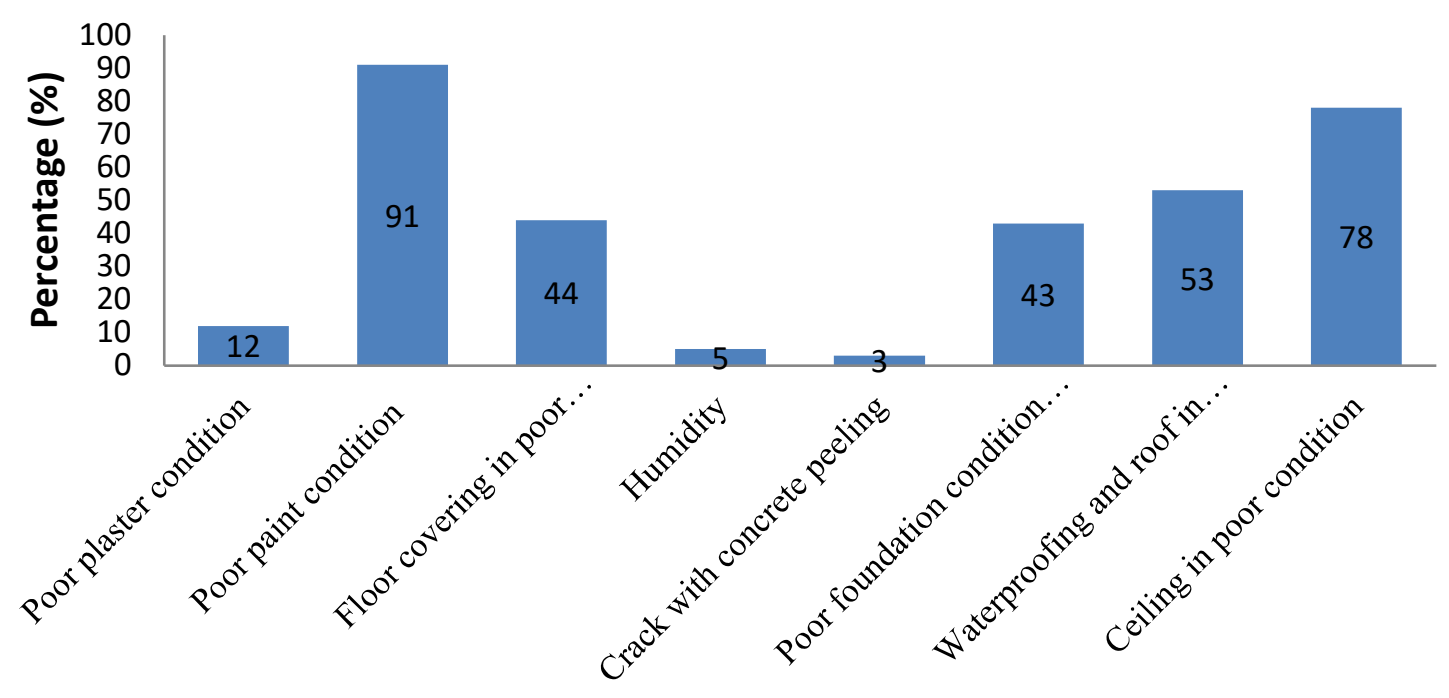

Série 1

Figure 14.Global histogram of the general aspect of public primary and secondary school buildings in the city of Bafoussam

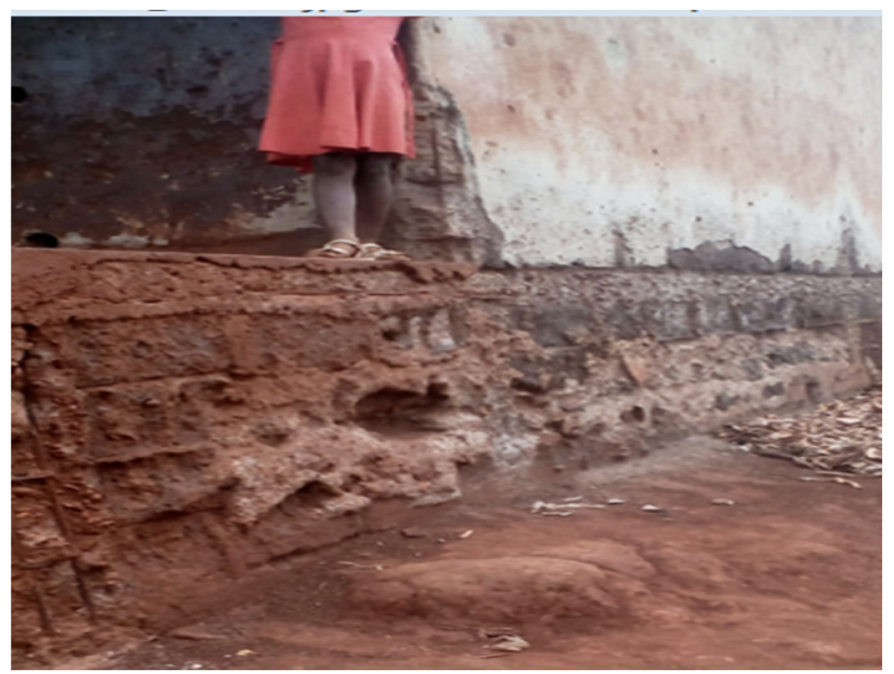

Figure 15.Foundation degradation

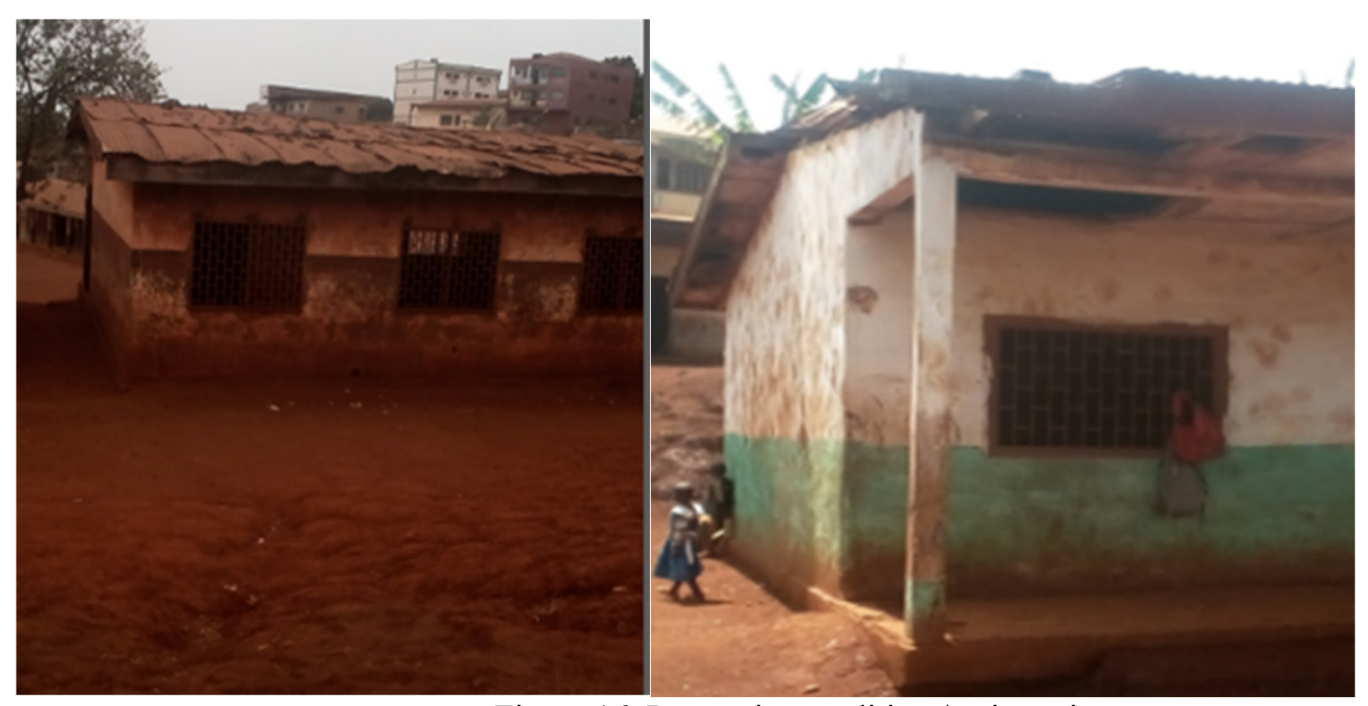

Figure 16. Poor paint condition / paint aging 


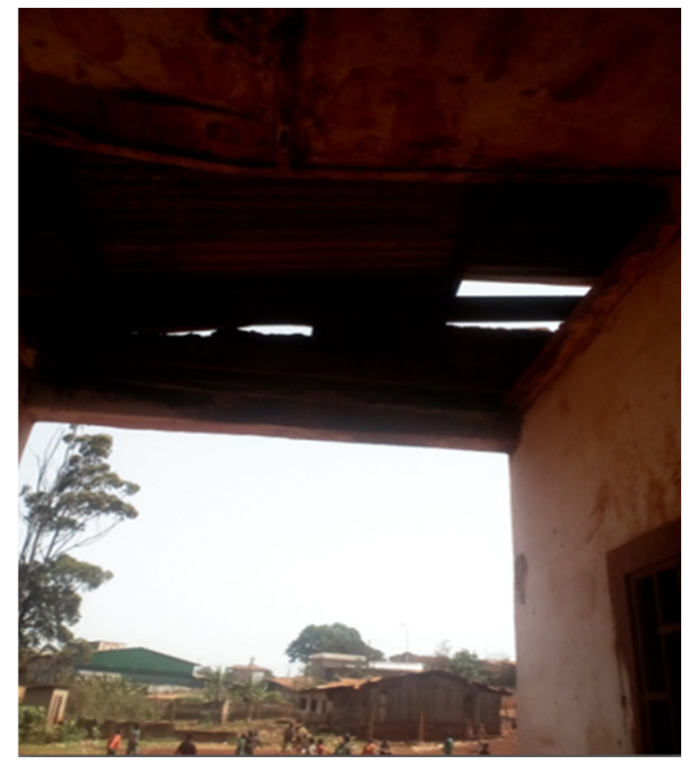

Figure 17. Defective ceiling

Table 5 and Figure 13 show the state of the plaster, paint, floor, ceiling, roof terrace, etc. of administrative primary and secondary schools buildings in the city of Bafoussam visited. Figure 14 shows the combined degradations or defects due to poor condition of the plaster, paint, floor, ceiling, roof terrace etc. of administrative primary and secondary schools buildings in the city of Bafoussam. We observe that some buildings have an attractive general appearance; others on the other hand, and in majority, have a disastrous face. The defects cited above have their origin in the students' incivism, acts of vandalism, insecurity in the schools, the poor quality of the work carried out, the use of unskilled labor, the aging and poor quality of the materials used, the lack of a sewerage network, faults building design and non-compliance with architectural standards.

$98 \%$ of primary school buildings in the city of Bafoussam show an aging of the paint on the walls, i.e. 127 buildings, while those of secondary school buildings show $86 \%$ i.e. 157 buildings. $85 \%$ of primary school buildings in the city of Bafoussam have a ceiling in poor condition i.e. 111 buildings, while those of secondary schools buildings have $76 \%$ i.e. 132 buildings.

The primary school buildings in the city of Bafoussam are more degraded than those of secondary schools in general aspect. Figure 16 and Figure 17 respectively illustrate the poor condition of the paint on the walls and the defective ceiling of some school buildings.

\section{Maintenance activities}

Maintenance work includes preventive maintenance and corrective maintenance. Preventive maintenance can be defined according to Cruzan (2009) (as cited in Sivanathan et al., 2012) as a scheduled program of regular inspections, adjustment, lubrication, or replacement of worn or failing parts in order to maintain an asset's function and efficiency, it is also "a set of activities performed while the building is still in a good or fair condition to inhibit progressive failure and therefore extend the service life of the building', and corrective maintenance is all the activities carried out after the failure of a building or the degradation of its function.

Preventive maintenance aims to reduce the probability of failure or damage of a building.

Maintenance work includes all monitoring, maintenance and renewal actions during the use of an asset.

\subsection{Maintenance - cleaning}

The maintenance-cleaning tasks of the premises and the external spaces of the school buildings of the primary and secondary schools of the city of Bafoussam are carried out in school time, by the students under the supervision of the school staff on a daily, weekly, quarterly basis. Daily tasks include cleaning the floor, gutters, toilets and latrines, picking up papers in the yard and traffic lanes. Weekly tasks include the organization of student manual work sessions by supervisory staff, consisting of cleaning the various equipment and quarterly tasks include the organization of manual student work sessions by supervisory staff, consisting of cleaning various equipment.

However, we noted that the maintenance-cleaning activities are done on irregular basis, without the use of suitable equipment and products such as detergents, bleach, liquid soaps, window cleaners, scented gel, etc...

\subsection{Preventive maintenance}

The information from the various survey sheets shows that no action is taken in the area of preventive maintenance in all schools in the city of Bafoussam. 


\subsection{Corrective maintenance}

Information from the survey sheets reveals that corrective maintenance of administrative school buildings is rare and very ineffective. The frequency is non-existent; the interventions are punctual but poorly executed in the rare cases carried out.

Table 6 presents the statistics of corrective maintenance activities undertaken on public school buildings in the city of Bafoussam over the past ten years. Combined corrective maintenance activities undertaken on electricity and fire safety, on plumbing and sanitary facilities etc. are shown in Figure 19.

Table 6. Corrective building maintenance statistics for the past decade

\begin{tabular}{|c|c|c|c|c|c|c|}
\hline \multirow{2}{*}{ Maintenance activities } & \multicolumn{2}{|c|}{ Primary schools } & \multicolumn{2}{c|}{ Secondary schools } & \multicolumn{2}{c|}{ Total } \\
\cline { 2 - 7 } & $\begin{array}{c}\text { Number of } \\
\text { buildings } \\
\text { maintained } / 130\end{array}$ & $\%$ & $\begin{array}{c}\text { Number of } \\
\text { buildings } \\
\text { maintained } / 182\end{array}$ & $\%$ & $\begin{array}{c}\text { Number of } \\
\text { buildings } \\
\text { maintained } / 312\end{array}$ & $\%$ \\
\hline General aspect & 04 & 03 & 20 & 11 & 24 & 08 \\
\hline Electricity and fire safety & 32 & 25 & 61 & 34 & 93 & 30 \\
\hline Sanitation and plumbing & 05 & 13 & 06 & 19 & 11 & 15 \\
\hline Carpentry & 04 & 03 & 18 & 10 & 22 & 07 \\
\hline Landscaping & 04 & 03 & 09 & 05 & 13 & 04 \\
\hline
\end{tabular}

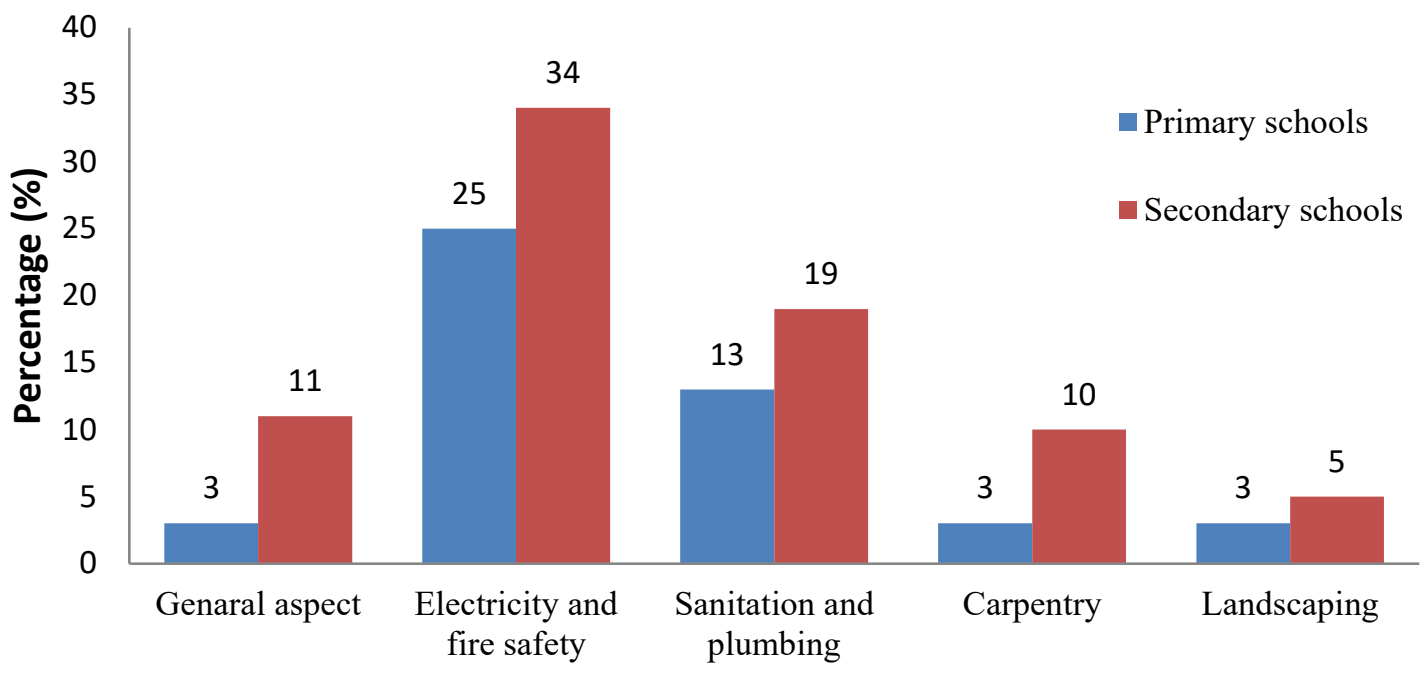

Figure 18. Histogram of maintenance activities of public school buildings in the city of Bafoussam

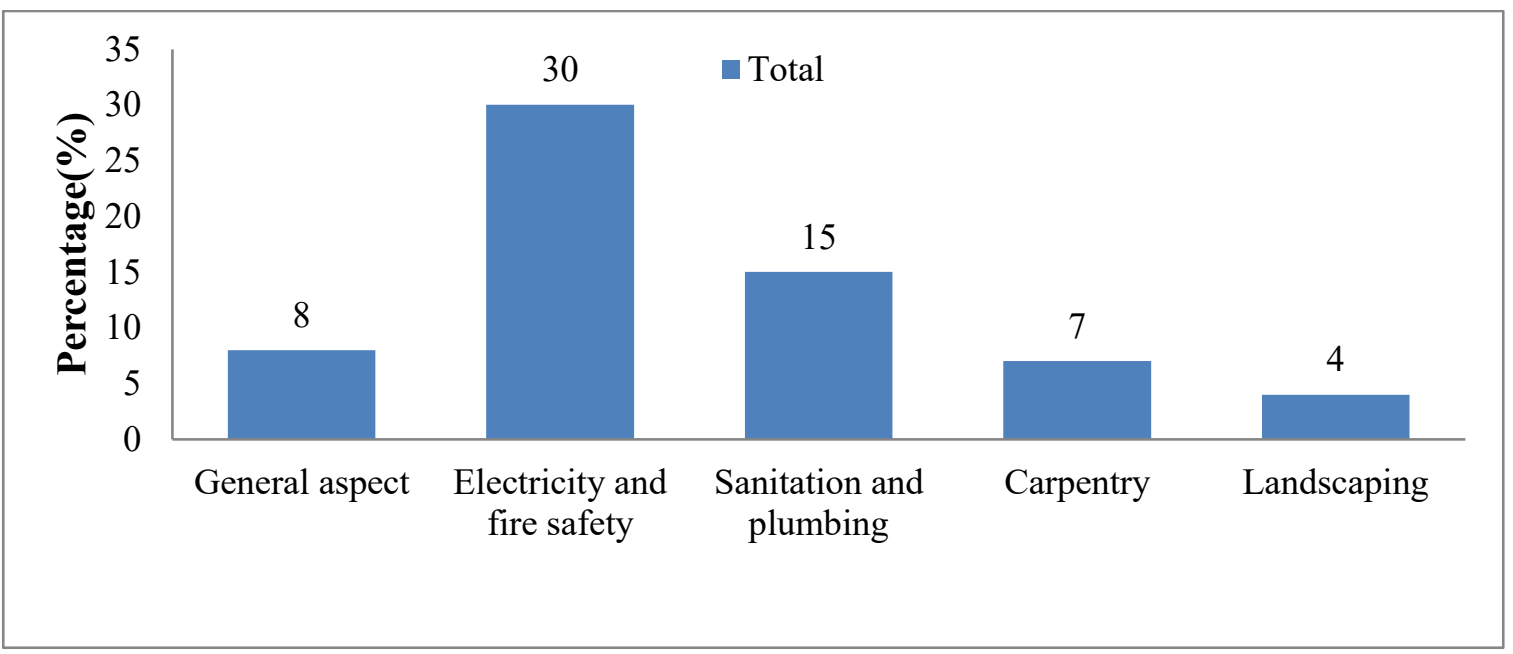

Figure 19.Global histogram of maintenance activities of public school buildings in the city of Bafoussam over the past ten years

Figure 18 and Table 6 sufficiently show the scarcity of maintenance activities for administrative school 
buildings in the city of Bafoussam; indeed, on average $8 \%$ of school buildings in general and only $3 \%$ of primary school buildings have been the subject of maintenance work relating to the general appearance during the last decade; that is to say a general annual average of $0.8 \%$, we can easily understand why these buildings present a dilapidated face and particularly those of primary schools.

$25 \%$ of primary school buildings in the city of Bafoussam have undergone maintenance work in the field of electricity and fire safety, i.e. 32 buildings, while $34 \%$ of those in school buildings in secondary schools have undergone maintenance work in the field of electricity and fire safety, i.e. 61 buildings. $13 \%$ of the primary school buildings in the city of Bafoussam have undergone maintenance work in the field of sanitation, plumbing and sanitary facilities, i.e. 5 buildings, while $19 \%$ of those in secondary school buildings have undergone maintenance work in the field of sanitation, plumbing and sanitary facilities, i.e. 6 buildings. The secondary school buildings in the city of Bafoussam have undergone more maintenance work than those of primary schools.

\section{Conclusions}

The aim of this study was to assess the degradations/defects and maintenance of administrative primary and secondary school buildings of the city of Bafoussam, Cameroon. To achieve this goal, we administered questionnaires to various managers of public primary and secondary schools in the three districts of Bafoussam namely, Bafoussam I, Bafoussam II and Bafoussam III. Based on data obtained, the following conclusions are drawn:

$\checkmark \quad$ The city of Bafoussam has nearly 46 schools including 31 primary schools and 15 secondary schools

$\checkmark$ The city of Bafoussam has 312 school buildings

$\checkmark$ The school buildings of primary schools in the city of Bafoussam are more degraded in the field of electricity and fire safety than those of secondary schools.

$\checkmark \quad$ The primary school buildings in the city of Bafoussam are more degraded than those of secondary schools in general aspect.

$\checkmark 78 \%$ of the primary school buildings of the city of Bafoussam present a very bad state in metallic joinery i.e. 102 of buildings, while $65 \%$ of secondary school buildings are in poor condition with metallic carpentry i.e. 119 buildings.

$\checkmark$ The secondary school buildings in the city of Bafoussam have undergone more maintenance works than those of primary schools as an example $25 \%$ of primary school buildings in the city of Bafoussam have undergone maintenance work in the field of electricity and fire safety, i.e. 32 buildings, while $34 \%$ of those of secondary schools have undergone maintenance work in the field of electricity and fire safety, i.e. 61 buildings.

$\checkmark \quad 87 \%$ of the school buildings in the city of Bafoussam are more than 10 years old, i.e. 271 buildings

$\checkmark \quad 50 \%$ are between 10 and 30 years old i.e. 156 buildings

$\checkmark \quad 27 \%$ are between 30 and 50 years old i.e. 84 buildings

$\checkmark \quad 10 \%$ an age between 50 and 100 years i.e. 31 buildings

$\checkmark \quad$ The majority of primary school buildings are old

\section{Acknowledgements}

The authors are very thankful to Dr Gautier Bikoko of the Department of Civil Engineering Science, University of Johannesburg, South Africa, for his insight on this article. The authors acknowledge also the various managers of public primary and secondary schools in the three districts of Bafoussam namely, Bafoussam I, Bafoussam II and Bafoussam III for taking part in the study.

\section{References}

Amadi, A. N., Eze, C. J., Igwe, C. O., Okumlola, I. A., \& Okoye, N. O. (2012). Architect's and Geologist's View on the Causes of Building Failures in Nigeria. Modern Applied Science, 6(6), pp. 31-38. http://dx.doi.org/10.5539/mas.v6n6p31.

Ayuba, P., Olagunju, R. E., \& Akande, O. K. (2012). Failure and Collapse of Buildings in Nigeria: The role of professionals and other participants in the building industry. Inter-disciplinary Journal of Contemporary Research in business, 4(6), pp. 1267-1272.

Babalola, H. I. (2015). Building collapse: Causes and Policy Direction in Nigeria. International Journal of Scientific Research and Innovative Technology, 2(8).

Bikoko, T.G.L.J., Tchamba, J.C. \& Okonta, F.N. (2019). A Comprehensive Review of Failure and Collapse of Buildings/Structures. International Journal of Civil Engineering and Technology, 10(3), pp. 187-198.

Bikoko, T.G.L.J. \& Okonta, F.N. (2016). Binder Systems for the Stabilization/Solidification of Contaminated Soils- A Review. Electronic Journal of Geotechnical Engineering, (21.25), pp. 9927-9960.

Eghan, G.E. (2014). Maintenance Management of Educational Infrastructure in Ghana: Development of a Framework for Senior High Schools, Master of Philosophy in Building Technology, Kwame Nkrumah 
University of Science and Technology, College of Architecture and Planning, Department of Building Technology

Olubi, A, R \& Adewolu, T, O (2018). Impacts and Building collapse on Sustainable Development in Nigeria. Civil and Environmental Research, 10(11), pp. 15-32.

Oseghale, G. E., Ikpo, I. J., \& Ajayi, O. D. (2015). Causes and Effects of building collapse in Lagos State, Nigeria. Civil and Environmental Research, 7(4), pp. 34-43.

Perret, J. (1999). Guide « Contrat de maintenance des bâtiments publics » p11.

Sivanathan, S., Jibril, J.D., Jivasangeeta, Thanaraju, P., Dodo, Y.A., \& Shika, S.A. (2012). An Overview of Design Deficiencies on Building Maintenance, OIDA International Journal of Sustainable Development, 05:11 (2012), pp. 105-111

Tauheed, I. A. (2007). Curbing the Collapse of buildings in Nigeria. Proceedings of the 1st Annual National Conference, School of Environmental Technology, 28th- 2nd March, FUT Minna, Nigeria, pp.37-39.

Tayeh, B.A., Khalid Al Hallaq, Fathi A. Sabha \& Moruf Olalekan Yusuf (2017). Effects of Construction Phase Errors on Maintenance of School Buildings in Gaza Strip, BEST: International Journal of Management, Information Technology and Engineering (BEST: IJMITE), Vol. 5, Issue 01, Jan 2017, pp. 21-34

Tayeh, B.A., Khalid Al Hallaq, \& Fathi A. Sabha (2016). Effects of Faulty Design Phase on School Buildings Maintenance in Gaza Strip, American Journal of Civil Engineering and Architecture, 4(6), pp. 199-210. DOI: 10.12691/ajcea-4-6-2

Tchamba, J.C. \& Bikoko, T.G.L.J. (2016). Failure and Collapse of Building Structures in the Cities of Yaoundé and Douala, Cameroon from 2010 to 2014, Modern Applied Science, 10(1), pp. 23-33. http://dx.doi.org/10.5539/mas.v10n1p23

Twumasi-Ampofo, K., Ofori, P. A., Osei Tutu, E., Cobinah, R., Twumasi, E. A. \& Kusi, S. (2017). Maintenance of Government Buildings in Ghana: The Case of Selected Public Residential Buildings In Ejisu-Ashanti, Journal of Emerging Trends in Economics and Management Sciences (JETEMS), 8(3): pp.146-154

Vom Tahi Onana, D., Ngwem Bayiha, B, Fokwa, D., \& Nzengwa. R. (2020). Evaluation of Primary and Secondary School Buildings in the City of Bafoussam, Cameroon, International Journal of Advanced Research in Engineering and Technology, 11(2), pp. 146-155.

Wuni, I.Y, Agyeman-Yeboah, S. \& Henry K. Boafo (2018). Poor Facility Management in the Public Schools of Ghana; Recent Empirical Discoveries, Journal of Sustainable Development Studies, 11(1), pp.1-30

\section{APPENDIX I}

\section{BAFOUSSAM I SCHOOLS}

Secondary schools

\begin{tabular}{|l|l|l|l|l|l|}
\hline $\mathrm{S} / \mathrm{N}^{\circ}$ & Name of school & $\begin{array}{l}\text { Total number of } \\
\text { buildings }\end{array}$ & $\begin{array}{l}\text { Classrooms and } \\
\text { other }\end{array}$ & Offices & $\begin{array}{l}\text { Latrine } \\
\text { blocks }\end{array}$ \\
\hline 1 & $\begin{array}{l}\text { L.Bde } \\
\text { NDIENGDAM }\end{array}$ & 14 & - & 2 \\
\hline 2 & L. C.de Bafoussam & 12 & 9 & 1 & 2 \\
\hline 3 & L. B. de Bafoussam & 16 & 13 & 1 & 2 \\
\hline 4 & Lycée de Bafoussam Batoukop & 13 & 10 & 1 & 2 \\
\hline 5 & L. T. de Bafoussam BANENGO & 20 & 17 & 1 & 2 \\
\hline 6 & L. T. de Bafoussam TAYIM & 11 & 8 & 1 & 2 \\
\hline & TOTAL & 86 & 69 & 5 & 12 \\
\hline
\end{tabular}


Primary schools

\begin{tabular}{|l|l|l|l|l|l|}
\hline S/N & Name of school & $\begin{array}{l}\text { Total number of } \\
\text { buildings }\end{array}$ & $\begin{array}{l}\text { Classrooms } \\
\text { and other }\end{array}$ & Offices & Latrine blocks \\
\hline 1 & E.P BADIENGSO I et II & 06 & 4 & - & 2 \\
\hline 2 & E.PBAMENDZI I A 1 et $A_{2}$ & 06 & 4 & - & 2 \\
\hline 3 & E. P BAMENDZI I B & 03 & 2 & - & 1 \\
\hline 4 & E. P BAMENDZI II A 1 et A 2 & 06 & 4 & - & 1 \\
\hline 5 & E. P BAMENDZI II B & 03 & 2 & - & 1 \\
\hline 6 & E. P BAMENDZIII & 03 & 2 & - & 1 \\
\hline 7 & E. PBANEFO BAFOUSSAM & 03 & 2 & - & 1 \\
\hline 8 & E. PBANENGO I A et B & 06 & 4 & - & 2 \\
\hline 9 & E. PBENENGO II A et B & 06 & 5 & - & 1 \\
\hline 10 & E. PBATOUKOP & 08 & 6 & - & 2 \\
\hline 11 & E. P CENTRE III A1 et B1 & 06 & 4 & - & 2 \\
\hline 12 & E. PDJELENG V A1 et A2 & 06 & 4 & - & 2 \\
\hline 13 & E. PDJELENG V B1 et B2 & 06 & 5 & - & 1 \\
\hline 14 & E. PDJEMOUN A et B & 06 & 5 & - & 1 \\
\hline 15 & E. PEVECHE & 03 & 2 & - & 1 \\
\hline 16 & E. PFAMLA & 03 & 2 & - & 1 \\
\hline 17 & E. PGENDRAMERIE A et B & 03 & 2 & - & 1 \\
\hline 18 & E. PNDIENGDAM I, II et III & 03 & 2 & - & 1 \\
\hline 19 & G.B.P.S. BATOUKOP & 03 & 2 & - & 1 \\
\hline 20 & G.B.P.S. NDIENGDAM & 03 & 2 & - & 1 \\
\hline 21 & EPTOMDJO & 03 & 2 & - & 1 \\
\hline 22 & G.B.P.S. TOMDJO & 03 & 70 & - & 1 \\
\hline & TOTAL & 98 & & 28 \\
\hline
\end{tabular}

\section{BAFOUSSAM II SCHOOLS}

Secondary schools

\begin{tabular}{|l|l|l|l|l|l|}
\hline S/N & Name of school & $\begin{array}{l}\text { Total number of } \\
\text { buildings }\end{array}$ & $\begin{array}{l}\text { Classrooms } \\
\text { and other }\end{array}$ & Offices & $\begin{array}{l}\text { Latrine } \\
\text { blocks }\end{array}$ \\
\hline 1 & L. B. de BALENG & 18 & 16 & 1 & 1 \\
\hline 2 & Lycée de TOUGANG II & 12 & 10 & - & 2 \\
\hline 3 & Lycée de KONTI & 09 & 8 & - & 1 \\
\hline & TOTAL & 39 & 34 & 1 & 4 \\
\hline
\end{tabular}

\section{Primary schools}

\begin{tabular}{|l|l|l|l|l|l|}
\hline $\mathrm{S} / \mathrm{N}^{\circ}$ & Name of school & $\begin{array}{l}\text { Total number of } \\
\text { buildings }\end{array}$ & $\begin{array}{l}\text { Classrooms } \\
\text { and other }\end{array}$ & Offices & $\begin{array}{l}\text { Latrine } \\
\text { blocks }\end{array}$ \\
\hline 1 & E. P. de FAMPI I & 03 & 2 & - & 1 \\
\hline 2 & E.P. NDIONKOU II & 04 & 3 & - & 1 \\
\hline 3 & E. P.DJASSAG et $_{2}$ & 03 & 2 & - & 1 \\
\hline & TOTAL & 10 & 7 & - & 3 \\
\hline
\end{tabular}

\section{BAFOUSSAM III SCHOOLS}

Secondary schools

\begin{tabular}{|c|c|c|c|c|c|}
\hline $\mathrm{S} / \mathrm{N}^{\circ}$ & Name of school & $\begin{array}{l}\text { Total number of } \\
\text { buildings }\end{array}$ & $\begin{array}{l}\text { Classrooms } \\
\text { and other }\end{array}$ & Offices & Latrine blocks \\
\hline 1 & Lycée Bafoussam KENA & 15 & 12 & 1 & 2 \\
\hline 2 & Lycée Bilingue de TOKET $_{\text {II }}$ & 12 & 10 & - & 2 \\
\hline 3 & Lycée Bilingue de GOUACHE & 15 & 13 & 1 & 2 \\
\hline 4 & $\begin{array}{ll}\text { Lycée de } & \text { Bafoussam } \\
\text { DJUNANG } & \\
\end{array}$ & 06 & 5 & - & 1 \\
\hline \multirow[t]{2}{*}{5} & L.T de Bafoussam CANADA & 09 & 7 & 1 & 1 \\
\hline & TOTAL & 57 & 49 & 03 & 08 \\
\hline
\end{tabular}


Primary schools

\begin{tabular}{|c|l|l|l|l|l|}
\hline $\mathrm{S} \mathrm{N}^{\circ}$ & Name of school & $\begin{array}{l}\text { Total number of } \\
\text { buildings }\end{array}$ & $\begin{array}{l}\text { Classrooms and } \\
\text { other }\end{array}$ & Offices & $\begin{array}{l}\text { Latrine } \\
\text { blocks }\end{array}$ \\
\hline 1 & E. P KENAG1 et G2 & 05 & 3 & 1 & 1 \\
\hline 2 & E.P de DJUNANG & 04 & 3 & - & 1 \\
\hline 3 & $\begin{array}{l}\text { E. P.A (G1, G2, G3, G4, G5) } \\
\text { Marie Rural }\end{array}$ & 03 & 2 & - & 1 \\
\hline 4 & EPA G 6 et G7 (Gouache) & 04 & 3 & - & 1 \\
\hline 5 & E.P. NDZE & 03 & 2 & - & 1 \\
\hline 6 & E.P. TOKETG1 et G2 & 03 & 2 & - & 1 \\
\hline & TOTAL & 22 & 15 & 1 & 6 \\
\hline
\end{tabular}

\section{APPENDIX II}

ESTABLISHMENT

\section{SURVEY SHEET}

BAFOUSSAM DISTRICT CREATION DATE

DATE :

1. How many buildings does the establishment have?

2. Does the establishment have an entire fence? Yes

3. How do the buildings look at first sight?

Dilapidated

Attractive

4. Does the establishment have a daycare service?

Yes

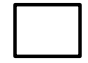

No

5. Where does the funding for the maintenance of your buildings come from?

Donations BIP

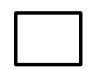

City hall

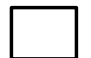

APEE

Contributions

\section{PREVENTIVE MAINTENANCE}

1. Is there a periodic monitoring method for the various buildings in your establishment?

Yes

No

If yes, what are the trades involved?

- $\quad$ Electricity and fire safety

- $\quad$ Sanitation, plumbing and sanitation facilities

- Carpentry

Major works

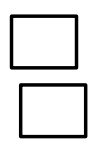

Finishes

2. What are the means used for surveillance?

Maintenance schedule

GMAO

3. By whom is this monitoring carried out?

Support staff

Specialized company

Particular

4. Is there a preliminary study of evaluation of repair work?

Yes

If yes, by whom?

Support staff
No

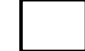




\section{MAINTAINS - CLEANING}

5. Who takes care of the cleaning of your premises?

Students

Support staff

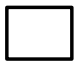

External company

6. What surfaces are cleaned regularly?

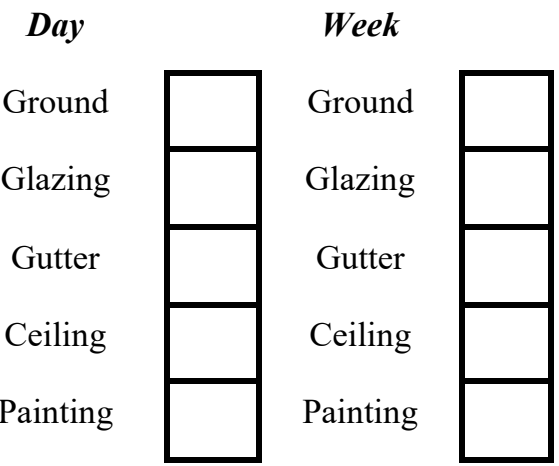

\begin{tabular}{l|l|}
\multicolumn{1}{l|}{ Month } \\
Ground & \\
\cline { 2 - 2 } Glazing & \\
Gutter & \\
Ceiling & \\
& \\
\cline { 2 - 2 } Painting &
\end{tabular}

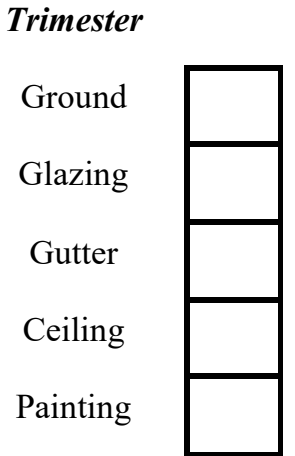

Year

7. How often is it cleaned?

Daily

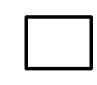

Weekly

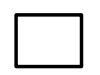

Monthly

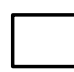

Quarterly

\section{CORRECTIVE MAINTENANCE}

8. Does the establishment have a building maintenance service? Yes

No

9. Is there a global maintenance of the various trades? Yes

No

10. How is a market or a maintenance task acquired?

Little by little

Tender

11. Is there a way to store light repair material if necessary?

Yes

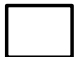

No

12. How often is the septic tank emptied?

01 year

02 years

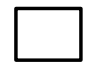

05 years

More

13. Is there a building maintenance frequency? Yes

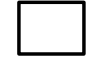

No

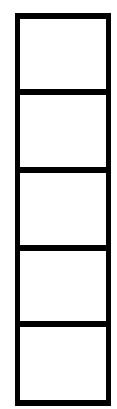

